\title{
FLOOD RISK ASSESSMENT OF ŁODŹ PROVINCE COMMUNES
}

\begin{abstract}
The main aim of the article is flood risk assessment on the flood hazard areas in 21 communes of the Łódź province. The area exposed to floods means an area that is probable to be covered by water once for 100 -years. The notion of flood risk is understood as "the combination of the probability of a flood event and of the potential adverse consequences for human health, the environment, cultural heritage and economic activity associated with a flood event" 2 . For flood risk assessment was used authorial method, where the primary field was an area of 0.5 ha hexagon. Author made the synthetic assessment of flood risk level and its diversification within the flood hazard area. The highest synthetic flood risk level is in Łowicz and Tomaszów Mazowiecki (town). On the Łowicz area the valley bottom of the Bzura river is very wide, especially in the western and eastern part where there are buildings. Tomaszów Mazowiecki is the town where smaller rivers flow into the Pilica river, which is why the valley bottom reaches there considerable sizes, thus fostering localization of buildings. Smaller rivers, especially the Czarna and Piasecznica rivers as well as the location below the Sulejowski reservoir, creates a sense of security among its users. All this leads to intensification of land development on this area and an increase in potential adverse consequences in the event of flooding. The analysis of flood risk levels is of paramount importance as it enables to implement a suitable anti-flood protection policy.
\end{abstract}

Keywords: areas exposed to floods, spatial development, flood risk, Floods Directive.

\section{INTRODUCTION}

High water levels within the floodplain belong to natural phenomena ${ }^{3}$. It is of great importance to introduce adequate anti-flood protection policy on the flood hazard areas. Methods of anti-flood protection used in Poland so far have been limited to technical activities ${ }^{4}$. These methods are not effective and lead to changes in the biodiversity on the

\footnotetext{
${ }^{1}$ Marta Borowska-Stefańska PhD, Department of the Building Environment and Spatial Policy, Faculty of Geographical Sciences, University of Lodz, ul. Kopcińskiego 31, 90-142 Łódź, email: borosia@op.pl

${ }^{2}$ Dyrektywa 2007/60/WE Parlamentu Europejskiego i Rady z dnia 23 października 2007 r. w sprawie oceny ryzyka i zarządzania nim (Dyrektywa Powodziowa), art. 2 pkt. 2.

${ }^{3}$ E. Kobojek, Środowisko przyrodnicze dolin rzek nizinnych i kierunki antropogenicznych przekształcen, [in:] Prawne, administracyjne i środowiskowe uwarunkowania zagospodarowania dolin rzecznych, ed. B. Więzik, Wyższa Szkoła Administracji w Bielsku Białej, Bielsko Biała 2010, p. 44.

${ }^{4}$ J. Bajorek, Wdrażanie rozwiazań proponowanych w planach: założenia i problemy praktyczne, „Gospodarka Wodna” 2001, No 8, p. 337.

E. Bobiński, J. Żelaziński, Czy można przerwać btędne koło ochrony przeciwpowodziowej?, „Gospodarka Wodna” 1996, No 4, p. 104.
} 
given area through decreasing the number of species of plants and animals which lived there previously ${ }^{5}$. Currently there has been a change in the approach to flood plain protection. The implementation of the Floods Directive (2007) at the end of 2013 resulted in development of maps of flood hazard and flood risk. Due to them everyone can check if the given area may be affected by floods. An important issue is leaving some "place" for the flood in all the places where the hazard to people and the economy is low. In the case of considerable urbanization, industralization and farming of riverside areas, there are restrictions concerning the possibilities of widening the trough and the valley ${ }^{6}$. This is conditioned by the specificity of the protected area. There are distinct differences in the course of flooding in valleys of big rivers (i.e. the Vistula River or the Oder) and small ones. The reason for huge damage caused by floods is, to a large extent, the state of buildings and land development of river valleys ${ }^{7}$. In flood hazard zones there are more and more public utility facilities, such as schools, museums, theatres, services, including filling stations as well as facilities which may generate secondary threats: landfill sites, water purification plants etc. On these areas there are also buildings which may cause a rise of water and consequently wider backwaters (ill-designed bridges, artificial valley narrowing). All this, combined with the conviction that technical devices are dependable, results in huge losses ${ }^{8}$. A surge in built-up areas on flood hazard zones tends to lead to increased extent and frequency of floods 9 .

The main aim of this work is to assess flood risk on flood hazard areas in the selected communes of the Łódź province. The analysis comprises 21 communes $^{10}$ which are located within the Łódź province in the catchment areas of three main rivers: the Warta, Pilica and Bzura and characterized by a high and very high flood risk indicator ${ }^{11}$.

It is considered that the flood hazard zone is an area to the level of 100-year water. In water management it is assumed that ,the main flood hazard zone is the zone described on the basis of the annual peak flow characterized by the probability of exceeding $p=1 \%$ " 12 .

T. Walczykiewicz, I. Biedroń, Zagospodarowanie dolin rzecznych w świetle zarzadzania ryzykiem powodziowym, [in:] Prawne, administracyjne i środowiskowe uwarunkowania zagospodarowania dolin rzecznych, ed. B. Więzik, Wyższa Szkoła Administracji w Bielsku Białej, Bielsko Biała 2013, p. 146.

${ }^{5}$ E. Bobiński, J. Żelaziński, op. cit., p. 104.

${ }^{6}$ T. Walczykiewicz, I. Biedroń, op. cit., p. 147.

${ }^{7}$ Program Bezpieczeństwa Powodziowego w regionie wodnym Środkowej Wisty, Warszawa 2012, p. 41.

${ }^{8}$ R. Bogdańska-Warmuz, J. Grela J., Konieczny R., Siudak M., Systemy ostrzeżeń powodziowych, [in:] Model kompleksowej ochrony przed powodzia w obszarze dorzecza górnej Wisty na przykładzie województwa małopolskiego, ed. M. Maciejewski, IMGW, Kraków (CD-ROM), 2000.

${ }^{9}$ C. P. Konrad, Effects of Urban Development on Flood, U.S. Department of the Interior, U.S. Geological Survey, 2003, http://pubs.usgs.gov/fs/fs07603/ (access: 20.09.2014 r.).

${ }^{10}$ The starting point for the methodological approach employed in the article is the flood risk index suggested by the Public Safety and Crisis Management Department of the Lodz City Office. It was applied to select 21 communes with very high and high flood risk for the next part of the research.

${ }^{11}$ Ocena zagrożenia powodziowego na obszarze województwa łódzkiego, Wydział Bezpieczeństwa i Zarządzania Kryzysowego, Łódzki Urząd Wojewódzki w Łodzi, Łódź 2012.

${ }^{12}$ R. Grocki, R. Eliasiewicz, Zagospodarowanie terenów zalewowych, seria: Ograniczanie skutków powodzi w skali lokalnej, Biuro koordynacji Projektu Banku Światowego, Wrocław 2001, p. 19. 


\section{THE ISSUE OF LAND DEVELOPMENT AND FLOOD RISK}

Spatial development is the condition of space, including land, buildings, technical, social and economic infrastructure facilities as well as the environment, resulting from all kinds of activities aimed at a man-made durable change in physical properties of land introduced in order to satisfy people's needs in a direct or indirect way ${ }^{13}$. The current state of spatial development is examined on the basis of analysis of land use ${ }^{14}$. The term "use" is understood by Liszewski ${ }^{15}$ as ,,[...]using something, benefiting from something in a rational way which brings possibly greatest advantage". Consequently, almost every human activity is reflected in the land and ,[...] performs a clearly defined and diverse function function" 16 .

River valleys are separate nature systems characterized by specific forms of geological structure, relief, water relations, climate as well as fauna and flora. These are precisely the features of the environment that condition and shape forms of human activity. The type of valley development has a strong impact on their natural values as well as anti-flood protection. On the areas where there is no urbanization the degree of nature conversion is directly related to the system of land use types. The highest degree of conversion is connected with cultivation areas, a lower one is related to grassland whereas the lowest one is typical of forest areas. All these factors lead to the growing fragmentation of river and valley environment. From the point of view of anti-flood protection the greatest emphasis is placed on the analysis of the degree of investment of these areas and identification of highest hazard spots, which is of key importance for their proper protection $^{17}$.

The development of flood hazard areas is also related to the notion of flood risk which is normally defined as the product of hazard (physical and statistical flood aspects), exposure (who and what is threatened with flood) and sensitivity (susceptibility of development elements to the hazard and ability to counteract and eliminate the consequences of the catastrophe $)^{18}$. Interaction of these three elements gives rise to the socalled "risk triangle"19.

13 J. Regulski, Planowanie przestrzenne, Państwowe Wydawnictwo Ekonomiczne, Warszawa 1985, pp. 14-16.

${ }^{14} \mathrm{~K}$. Bromek, R. Mydel, Uwagi metodyczne do opracowania szczegółowej mapy użytkowania ziemi przestrzeni miejskiej, „,Folia Geopgraphica Seria Geographica-Oeconomica” 1972, Vol.5 Kraków Oddział PAN w Krakowie, p. 157.

${ }^{15}$ S. Liszewski, Przestrzeń miejska i jej organizacja, Geografia. Człowiek. Gospodarka, Kraków 1997, p. 61.

${ }^{16}$ S. Liszewski, Tereny miejskie. Podziat i klasyfikacja, „Acta Universitatis Lodziensis. ZNUŁ. Nauki Matematyczno-Przyrodnicze, Folia Geographica" 1978, s. II, z. 15, p. 17.

${ }^{17}$ A. Słonecka, E. Jaglak, E. Goryszewska, J. Kołakowska, E. Ulanicka, Zagospodarowanie przestrzenne dolin rzecznych a zagrożenie powodziowe województwa mazowieckiego, Mazowieckie Biuro Planowania Regionalnego, Warszawa 2008, p. 55.

${ }^{18}$ H. Apel, G. T. Aronica, H. Kreibich, A. H. Thieken, Flood risk analyses-how detailed do we need to be?, "Natural Hazards" 2009, vol. 49, no. 1, p. 80.

${ }^{19}$ D. Crichton, The risk triangle [in:] Natural disaster management, ed. J. Ingleton, London: Tudor Rose, 1999, pp. 102-103.

D. Crichton, What can cities do to increase resilience? "Philosophical Transactions of the Royal Society" 2007, Vol. 365, p. 2734. 
The character, type and value of the existing land development on the flood hazard areas determine the level of losses which may occur in the form of damage or destruction of facilities resulting from flooding ${ }^{20}$. The total risk comprises the expected death toll, the injured, material loss and disruptions to economic activity in connection with the natural phenomenon. ${ }^{21}$ To put it in the simplest possible way, this is the probability of a flood event and consequences connected with it. They may be desirable or not ${ }^{22}$. These definitions were adopted in the Floods Directive where the notion of flood risk is understood as "the combination of the probability of a flood event and of the potential adverse consequences for human health, the environment, cultural heritage and economic activity associated with a flood event" ${ }^{23}$.

\section{FLOOD RISK ASSESSMENT IN THE LIGHT OF LITERATURE}

Damages due to floods are a consequence of the conflict between nature and using land by man. The type and scope of damage is constantly changing together with the development of the society ${ }^{24}$. There are different types of damage connected with the life of people and animals, vegetation, economic losses. All these elements add up to potential maximum damages ${ }^{25}$. Such damages may be divided into direct and indirect ones. The direct ones comprise these damages which occur as a result of direct influence of water on people, property or the environment whilst indirect damages include, for example, disruptions to traffic, losses resulting from limiting production due to the damaged infrastructure. The two types of damages tend to be classified in a more detailed manner as tangible property and intangible property depending if they can be assessed in money or not. The biggest part of literature concerning loss assessment refers to direct measurable losses ${ }^{26}$. Intangible damages are not taken into account as it is believed that

\footnotetext{
${ }^{20}$ J. Chojnacki, Szacowanie strat powodziowych, [in:] Model kompleksowej ochrony przed powodzia w obszarze dorzecza górnej Wisty na przykładzie województwa małopolskiego, ed. M. Maciejewski, IMGW, Kraków CD-ROM, 2000.

${ }^{21}$ UN DHA, Internationally Agreed Glossary of Basic Terms Related to Disaster Management. UN DHA (United Nations Department of Humanitarian Affairs), Geneva, 1992, p.64.

K. Granger, T. Jones, M. Leiba, G. Scott, Community Risk in Cairns: A Multi-hazard Risk Assessment. AGSO (Australian Geological Survey Organisation) Cities Project, Department of Industry, Science and Resources, Australia 1999, p.30.

${ }^{22}$ P. B. Sayers, B. P. Gouldby, J. D. Simm, I. Meadowcroft, J. Hall, Risk Performance and Uncertainty in Flood and Coastal Defence - A Review, R\&D Technical Report FD2302/TR1 (HR Wallingford Report SR587), Crown copyright, London, U.K. 2002, p.5.

${ }^{23}$ Dyrektywa 2007/60/WE Parlamentu Europejskiego i Rady z dnia 23 października 2007 r. w sprawie oceny ryzyka i zarządzania nim (Dyrektywa Powodziowa), art. 2 pkt. 2.

${ }^{24}$ ICPR, International commission for the protection of the Rhine, "Non-structural flood plain management: Measures and their effectiveness", Koblenz, 2002, http://www.iksr.org/index.php (access: 20.09.2014 r.).

${ }^{25} \mathrm{E}$. Genovese, A methodological approach to land use-based flood damage assessment in urban areas: Prague case study, European Communities, 2006, p.18.

${ }^{26}$ A. H. Thieken, M. Müller, H. Kreibich, B. Mer, Flood damage and influencing factors: New insights from the August 2002 flood in Germany, "Water Resources Research" 2005, 41 p. 1.
} 
their share in total damages is inconsiderable ${ }^{27}$. The main idea behind flood loss assessment is the notion of the function of damage and the function of losses. The majority of functions of losses coincide in the fact that the direct financial loss is connected with the kind and or use of the building and the depth of flooding ${ }^{28}$. The most frequent damage functions for buildings are elaborated on the basis of the data collected after floods ${ }^{29}$. Data on anticipated losses may be also assessed by owners of facilities or specialists on the basis of field surveys. In that case analysis comprises statistical data on individual value of separate investment types in order to elaborate curves of individual losses for different categories of facilities. Generally speaking, however, in all these methods there is a tendency to condition the value of losses on the depth of flooding ${ }^{30}$. The result for most functions of losses is the absolute financial loss for the building, some approaches ensure relative damage functions and in this case the loss is expressed as a percentage loss of the value of the building ${ }^{31}$. When these functions are defined for assessing loss due to the given flood scenario, the property value must be given in advance $^{32}$. Flood damage depend on a number of factors, such as: flow speed, flood duration, contamination, water levels, information (flood warnings) etc. ${ }^{33}$. These aspects, however, are rarely taken into account in flood loss models, most frequently only the depth of flooding is considered ${ }^{34}$. Ignoring social or economic system susceptibility indicators i.e. the risk awareness or the degree of preparation for a flood event results in greater losses, which is confirmed by German research according to which preparing the ground floor of a single-family house for being flooded reduces the losses by 5-30\%. The range of reduction, nonetheless, depends on the depth of water ${ }^{35}$. It must be stressed that the main task in the process of assessing flood risk is to get to know in detail what the investment conditions on flood hazard areas is ${ }^{36}$.

In Poland the problem of development of flood hazard areas and assessment of losses due to flooding is dealt with by the National Water Management Authority (Polish: KZGW), the Institute of Meteorology and Water Management (Polish: IMGW), the Head Office of Land Surveying and Cartography (Polish: GUGiK), the Crisis Management Centre (Polish: RCB) and the National Institute of Telecommunications. There is a project entitled "IT System of the Country's Protection against extreme hazards," which resulted

\footnotetext{
${ }^{27}$ F. Messner, V. Meyer, Flood damage, vulnerability and risk perception - challenges for flood damage research, UFZ Discussion Paper 13, 2005 p. 160.

${ }^{28}$ H. G. Wind, T. M. Nierop, C. J. de Blois, J. L. de Kok, Analysis of flood damages from the 1993 and 1995 Meuse flood, "Water Resources Research"1999, Vol. 35, No. 11, p. 3460.

${ }^{29}$ A. H. Thieken, M. Müller, H. Kreibich, B. Mer, op. cit., p. 2.

${ }^{30}$ J. Chojnacki, Szacowanie strat powodziowych, op. cit.

${ }^{31}$ D. Dutta, S. Herath, K. Musiake, A mathematical model for flood loss estimation, "Journal of Hydrology" 2003, Vol. 277, No. 1, p. 29.

32 A. H. Thieken, M. Müller, H. Kreibich, B. Mer, op. cit., p. 2.

${ }^{33}$ I. Kelman, R. Spence, An overview of flood actions on buildings, "Engineering Geology" 2004, 73, p. 298.

J. Nicholas, G. D. Holt, D. Proverbs, Towards standardising the assessment of flood damaged properties in the UK, "Structural Survey" 2001, Vol. 19, No. 4, p. 166.

${ }^{34}$ A. H. Thieken, M. Müller, H. Kreibich, B. Mer, op. cit., p. 2.

${ }^{35}$ M. Sowiński, Szkody powodziowe jako element wyznaczania ryzyka, ,Infrastruktura i ekologia terenów wiejskich" 2008, Polska Akademia Nauk, Oddział w Krakowie, No 7, p. 130.

${ }^{36}$ J. Chojnacki, Szacowanie strat powodziowych, op. cit.
} 
in preliminary assessment of flood risk, flood hazard maps and flood risk maps. Flood hazard maps and flood risk maps were published at the end of 2013, yet guidelines providing for them were established already in the Regulation of the Minister of the Environment, the Minister of Transport, Construction and Marine Economy, the Minister of Administration and Digitalization and the Minister of Internal Affairs as of 21 December 2012 on elaboration of flood hazard maps and flood risk maps. These documents had to be elaborated in accordance with the provisions of the Floods Directive $^{37}$. The main aim of this document is to reduce the flood risk and minimize the consequences of floods, adequate management of the risk which may be posed by floods for human health, the environment, economic activity and cultural heritage as well as preparation of citizens to deal with a flood event ${ }^{38}$. This is the only document which clearly refers to flood risk assessment in Poland. It lacked, however, differentiation of flood risks within the flood hazard areas.

\section{INDEPENDENT RESEARCH METHODOLOGY}

In the absence of a single effective methodology of flood risk assessment, the author has proposed its own methodology for determining its level. On the basis of analysis of current development of flood hazard areas in the selected communes of the Łódź province, facilities and areas generating flood risk were identified. Due to their considerable differentiation within the limits of 100-year water four categories were distinguished:

- $\quad$ social facilities in which there might be a large number of people on a permanent or temporary basis,

- cultural heritage sites and natural value areas,

- facilities potentially representing a hazard to the environment and people,

- $\quad$ areas generating economic losses.

\section{Categories of flood risk}

The group of social facilities includes:

- $\quad$ residential buildings (both single family and multi-family buildings),

- hospitals,

- schools,

- kindergartens,

- hotels,

- health institutes.

The category of cultural heritage facilities and areas of natural value comprise:

- Natura 2000 areas,

- nature reserves,

- nature parks,

\footnotetext{
${ }^{37} \mathrm{http}: / /$ www.kzgw.gov.pl/Dyrektywa-Powodziowa.html (acceess: 27.11.2013).

${ }^{38}$ Rotnicka J., Gospodarka wodna w świetle uwarunkowań Unii Europejskiej [in:] Stan gospodarki wodnej w Polsce - problematyka prawna i kompetencyjna (na przykładzie Dolnej Wisły), Materiały z konferencji zorganizowanej przez Parlamentarny Zespół ds. Dróg Wodnych i Turystyki Wodnej 2 czerwca 2011 r. w siedzibie Senatu, Kancelaria Senatu, p. 21;
} 
- zoos

- $\quad$ areas and buildings of historical monuments, in particular those covered by the forms of monument protection which are referred to in article 7 point 1 of the act as of 23 July 2003 on the monument protection and care ${ }^{39}$,

- monuments placed on the World Heritage Site which is referred to in article 11 point 2 of the Convention Concerning the Protection of the World Cultural and Natural Heritage adopted in Paris on 16 November 1972 by the General Conference of the United Nations Educational, Scientific and Cultural Organization on its seventeenth session, ${ }^{40}$

- $\quad$ open-air ethnographic museums and museums entered into the National Register of Museums which are referred to in article 13 of the act 1996 on museums as of 21 November ${ }^{41}$.

In the group of facilities which may potentially represent a risk both to people and the environment in the event of a flood include:

- $\quad$ sewage purification plants,

- filling stations,

- pumping stations,

- landfill sites,

- waste management plant,

- animal farms.

Asaessment of tanglible losses was accomplished using the Database of Topographic Objects (Polish: BDOT). Under the Regulation of the Minister of the Environment, the Minister of Transport, Construction and Marine Economy, the Minister of Administration and Digitalization and the Minister of Internal Affairs as of 21 December 2012 on elaboration of flood hazard maps and flood risk maps in order to specify potential property loss on flood hazard areas, the following land use areas should be distinguished: housing estates, economic activity areas, transportation areas, forests, recreation sites, agricultural land, waters, the remaining areas for which flood losses are not determined.

Flood risk assessment on areas of particular flood hazard is a task of great importance as it makes is it possible to conduct activities connected with anti-flood protection in a rational way $^{42}$. It refers to assessment of the extent of damage of all categories for individual flood scenarios in the spatial system, and its effectiveness is largely dependent on topographic data available ${ }^{43}$.

In all distinguished categories the author made assessment of flood risk from the minimum level (1) to very high (5), where the base field was a hexagon of the surface of

\footnotetext{
${ }^{39}$ Dz.U. 2003 Nr 162 poz.1568, z późn. zm.

${ }^{40}$ Dz.U. 1976 Nr 32 poz. 190

${ }^{41}$ Dz.U. 2012 poz. 987

42 M. Szypuła, Strefy zagrożenia powodziowego: metodyka określania rodzajów i sposób wyznaczania z wykorzystaniem numerycznego modelu terenu, „Gospodarka Wodna” 2001, No 8 pp. 328-329.

${ }^{43}$ E. Nachlik, Wykorzystanie BDOT w ocenie ryzyka powodziowego - Problemy integracji przestrzennych informacji bazodanowych, VII Krakowskie Spotkania z INSPIRE, Georeferencyjne dane przestrzenne w INSPIRE - od zbiorów do usług danych przestrzennych, Kraków, 12-14 maja 2011.
} 
$0.5 \mathrm{ha}^{44}$. Subsequently a map was created which included a synthetic assessment of flood risk levels on the researched areas.

In the group of social facilities, cultural heritage and areas of natural value as well as facilities potentially representing a hazard for the environment and people, the area which they occupy in every hexagon was taken into consideration while assessing the flood risk level ${ }^{45}$. The hexagon area $(0.5 \mathrm{ha})$ was divided into 5 equal classes (every $0.1 \mathrm{ha}$ ): the larger the surface within the hexagon occupied by buildings or facilities of the given risk category, the higher its level. If facilities or areas occupied the area of up to $1,000 \mathrm{~m}^{2}$ in the hexagon (yet no more than 0), they received minimal risk level (1), from1,001to $2,000 \mathrm{~m}^{2}$ - very low risk level (2), form 2,001 to $3,000 \mathrm{~m}^{2}$-medium risk level (3), from 3,001 to $4,000 \mathrm{~m}^{2}$ - high risk level (4), >4,000 $\mathrm{m}^{2}$ - very high risk level (5).

Assessment of economic losses was made analyzing 7 selected areas of land use in every hexagon. The value of individual losses for residential areas, economic activity areas and transportation areas is closely related to the depth of water, and consequently to the extent of property value loss (table 1).

Table 1. The degree of loss of property due to the function and the depth of water

\begin{tabular}{|l|c|}
\hline \multicolumn{1}{|c|}{ Class of land use } & $\begin{array}{c}\text { Loss function value f }(\mathbf{h})[\%] \text { in the range } \\
\text { water depths } \mathbf{0 , 5}<\mathbf{h} \leq \mathbf{2} \mathbf{~ m}\end{array}$ \\
\hline Residential areas & 35 \\
\hline Economic activity & 40 \\
\hline Transportation areas & 10 \\
\hline
\end{tabular}

Source: Dz. U. 2013 poz. 104.

The potential value of economic losses was determined for the depth of water in the range of $0.5-2 \mathrm{~m}$. It is only when three elements are taken together: land use, depth of water and property value (which for residential and economic activity areas varies according to the province) that potential losses counted in money can be assessed (table 2).

\footnotetext{
44 The areas exposed to floods in all the researched communes were divided in the Geospatial Modelling Environment programme into hexagons of the surface of 0.5 ha. The hexagon size was adjusted in such a way so as to fit as many full figures within the boundaries of the analyzed area as possible.

45 Assessment of flood risk levels were made under the assumption that the depth of flooding ranges from 0.5 to $2 \mathrm{~m}$. This resulted from the specificity of floods on the area of the Łódź province. Consequently, in three categories of problem areas it was decided to take into account the surface of the facilities attributed to every selected group. In the case of buildings flooding within the analyzed range of water depth will take place only to the level of the first storey. Consequently, the analysis does not consider the number of storeys.
} 
Table 2. The value of property loss in the Łódź province due to land use class

\begin{tabular}{|c|c|}
\hline Class of land use & $\begin{array}{l}\text { The value of assets in the range water } \\
\text { depths } 0,5<\mathrm{h} \leq 2 \mathrm{~m}\end{array}$ \\
\hline Residential areas & $101,83 \mathrm{zl} / \mathrm{m}^{2}$ \\
\hline Economic activity & $331,68 \mathrm{zl} / \mathrm{m}^{2}$ \\
\hline Transportation areas & $43,6 \mathrm{zl} / \mathrm{m}^{2}$ \\
\hline Forests & $80 \mathrm{zl} / \mathrm{ha}$ \\
\hline Recreational areas & $5,1 \mathrm{zl} / \mathrm{m}^{2}$ \\
\hline Arable land & $1428 \mathrm{zl} / \mathrm{ha}$ \\
\hline Grassland & $674 \mathrm{zl} / \mathrm{ha}$ \\
\hline
\end{tabular}

The method of assessing property proposed in the Regulation was based on the methodology used in Germany ${ }^{46}$. It must be remembered, however, that due to fluctuations in prices these data must be updated so as to preserve comparability of the amount of damage and loss ${ }^{47}$.

While assessing the risk connected with potential economic losses the area occupied by selected land use classes was calculated in every hexagon. Then the property value was estimated for each of them and summed up within the base field (hexagon). The maximum risk level was assumed to be the value of losses for economic activity areas. The maximum value of losses in the hexagon was 1,658. 4 thousand PLN. Five equal ranges of property value were established (every 331.68 thousand PLN) and for every of them the level of risk was established ranging from minimal to very big, receiving a picture of flood risk levels according to economic loss.

In order to differentiate communes according to flood risk levels the share of hexagons in the given extent of risk was analyzed for 100-year water in every distinguished category. Only hexagons of the surface exceeding 0.4 ha were taken into account since only within their boundaries it was possible to receive the highest flood risk level. These hexagons whose surface was smaller were removed from the analysis. Subsequently a ranking of communes was elaborated in every category of flood risk according to the pattern:

$P=\frac{\sum U^{*} R i-g o}{5}$

where: $\mathrm{P}$ - risk level in the given category,

$\mathrm{U}$ - share of hexagons of the given category of flood risk in the area of 100-year water of the given commune,

$\mathrm{R}_{\mathrm{i}-\mathrm{go}}-$ extent of risk in the given category of flood risk,

\footnotetext{
${ }^{46}$ E. Drożdżal, M. Grabowski, K. Kondziołka, J. Olbracht, M. Piórecki, R. Radoń, Ryłko A., Mapy ryzyka powodziowego - projekt pilotażowy w zlewni Silnicy, „Gospodarka Wodna” 2009, No 1, p. 19.

${ }^{47}$ J. Chojnacki, Wskaźniki strat powodziowych, „Gospodarka Wodna” 1994, No 10, p. 227.
} 
5 - number of risk levels ${ }^{48}$.

As a result of these calculations values for all communes were obtained in every distinguished category and they were ranked in descending order in accordance with the obtained values and on this basis a ranking of communes was elaborated according to the flood risk. Finally, synthetic flood risk level was analyzed on the floodplain. In this classification the position of the given commune according to the flood risk level was taken into consideration in every distinguished category. The position of the commune indicated the number of points where the fewer the points, the higher total risk level.

\section{RESEARCH RESULTS}

In the group of facilities where people may stay on a temporary or permanent basis the highest flood risk may be found in Kutno, Radomsko, Tomaszów Mazowiecki (town) and Łowicz. These facilities are dispersed on the floodplain and they comprise mainly singlefamily residential buildings. In Łowicz within the limits of 100-year water there are also multi-family residential buildings (a housing estate). The group in question also comprises a district hospital (the commune of Gidle), schools (the commune and town of Tomaszów Mazowiecki, Radomsko), kindergarten (Łowicz), hotels (Uniejów, Rozprza, the town of Sieradz, Inowłódz), the Health Institute (Uniejów). People are more willing to invest on the areas of smaller basins, in towns and in places where fill terraces are wide.

Facilities posing the highest potential hazard for the environment and people in the event of flooding generate the highest risk in Tomaszów Mazowiecki (town), Łowicz oraz Kutno. In Tomaszów Mazowiecki (town) and Łowicz the biggest potential adverse consequences for the environment and people are related to the sewage purification plant which should be located outside the area of particular flood hazard and be equipped with individual security devices. These facilities were built in a place where the valley floor is wide.

As a result of an analysis of flood risk levels conducted on the basis potential property losses, Tomaszów Mazowiecki (town) was first on the list followed by Kutno, Łowicz and Działoszyn. This is mainly due to the degree of horizontal intensity of development. In Tomaszów Mazowiecki approximately 14\% of flood hazard areas is developed mainly with technical and production facilities, and the biggest potential losses may occur in the event of flooding in the area situated on the Czarna and the Piasecznica rivers. In Kutno the indicator of horizontal intensity of development for flood hazard areas was $7.5 \%$, which is an example illustrating that smaller rivers give greater sense of security. People are more willing to build in their valleys, which may lead to tragic consequences as floods in smaller valleys are more dynamic and it is more difficult to safeguard against them.

In the group of natural value areas and cultural heritage sites the highest risk levels can be found in Uniejów, Warta and Żytno communes (these are areas of Natura 2000). This is connected with, above all, the existence of natural value areas. Within their boundaries there are cubic and linear buildings as well as changes to land use. This phenomenon is very disadvantageous from the point of view of nature, there is still a lack of social

\footnotetext{
${ }^{48}$ The level of flood the given category goes up together with the increase in the share of hexagons of the highest level of this risk. The pattern was elaborated by the author of this article.
} 
acceptance for protection of areas of great natural beauty ${ }^{49}$ and as a result there is a risk that in the event of flooding these areas will lose their value. This is why they are taken into account in the assessment of flood risk (assuming the worst-case scenario as the influence of high water levels on these areas is definitely beneficial). This category also comprises cultural heritage facilities i.e. the ethnographic park, Castle Hill (the town of Sieradz), the open-air ethnographic museum of the Pilica river (the town of Tomaszów Mazowiecki), the castle of Uniejów, the milling cottage (Uniejów), the old synagogue (Inowłódz).

The highest synthetic flood risk level can be found in Łowicz and Tomaszów Mazowiecki (town). On the Łowicz area the valley bottom of the Bzura river is very wide, especially in the western and eastern part where there are buildings (the central section of the river within the town administrative boundaries was embanked). The conflict of development is also marked on the area of the land slide of the levee (remaining beyond the scope of the analysis). Tomaszów Mazowiecki is the town where smaller rivers flow into the Pilica river, which is why the valley bottom reaches there considerable sizes of about $1.7 \mathrm{~km},{ }^{50}$ thus fostering localization of buildings. Smaller rivers, especially the Czarna and Piasecznica rivers as well as the location below the Sulejowski reservoir, creates a sense of security among its users. All this leads to intensification of land development on this area and an increase in potential adverse consequences in the event of flooding. Due to sealing of the surface (through land development) infiltration of water to the soil is limited, increasing at the same time the outflow capacity ${ }^{51}$.

\section{CONCLUSIONS}

Analysis of flood risk levels is of great importance and it enables to conduct a suitable anti-flood protection policy. To achieve this it is invaluable to know both the synthetic assessment of flood risk level and its diversification within the flood hazard area. Due to this it is possible to determine which places are particularly susceptible to adverse consequences. Unfortunately, this element is missing on flood risk maps which were elaborated as part of the Floods Directive. The methodology proposed by the author of this article bridges this gap, yet analyses conducted using it refer only to areas of 100-year water in selected communities, which is in accordance with the provisions of law in force yet it does not meet the natural determinants of wide valley bottoms in Central Poland. But there is still no one single effective method of marking the flood risk level. It is of great importance in the process of analyzing flood consequences to pay attention not only

\footnotetext{
${ }^{49}$ M. Borowska-Stefańska, Zagospodarowanie terenów zagrożonych powodziami w matych miastach województwa tódzkiego [in:] Nowoczesne instrumenty polityki rozwoju lokalnego zastosowanie i efekty w matych miastach, eds. K. Heffner, M. Twardzik, "Studia Ekonomiczne. Zeszyty Naukowe Uniwersytetu Ekonomicznego w Katowicach" 2013, Wydawnictwo Uniwersytetu Ekonomicznego w Katowicach, Katowice, p. 330.

50 B. Trzmiel, Szczegótowa Mapa Geologiczna Polski, 1:50 000, arkusz 667-Tomaszów Mazowiecki, Państwowy Instytut Geologiczny, Warszawa, 1986.

${ }^{51} \mathrm{~W}$. Ripl, Management of water cycle and energy flow for ecosystem control: The energytransport-reaction (ETR) model, "Ecological Modelling" 1995, Vol. 78, p. 68.
} 
to tangible damage but also to intangible damage which is difficult to assess yet vital in the process of risk management.

\section{LITERATURE}

[1] Apel H., Aronica G. T., Kreibich H., Thieken A. H., Flood risk analyses-how detailed do we need to be?, "Natural Hazards" 2009, Vol. 49, No. 1, pp. 79-98.

[2] Bajorek J., Wdrażanie rozwiazań proponowanych $w$ planach: założenia $i$ problemy praktyczne, „Gospodarka Wodna” 2001, No 8, pp. 337-338.

[3] Bobiński E., Żelaziński J., Czy można przerwać błędne koło ochrony przeciwpowodziowej?, „Gospodarka Wodna” 1996, No 4, pp. 99-107.

[4] Bogdańska-Warmuz R., Grela J., Konieczny R., Siudak M., Systemy ostrzeżeń powodziowych, [in:] Model kompleksowej ochrony przed powodzia $w$ obszarze dorzecza górnej Wisty na przyktadzie województwa małopolskiego, ed. M. Maciejewski, IMGW, Kraków, (CD-ROM), 2000.

[5] Borowska-Stefańska M., Zagospodarowanie terenów zagrożonych powodziami w małych miastach województwa łódzkiego [in:] Nowoczesne instrumenty polityki rozwoju lokalnego - zastosowanie $i$ efekty $w$ matych miastach, eds. K. Heffner, M. Twardzik, „Studia Ekonomiczne. Zeszyty Naukowe Uniwersytetu Ekonomicznego w Katowicach" 2013, Wydawnictwo Uniwersytetu Ekonomicznego w Katowicach, Katowice, pp. 323-332.

[6] Bromek K., Mydel R., Uwagi metodyczne do opracowania szczegółowej mapy użytkowania ziemi przestrzeni miejskiej, „Folia Geopgraphica Seria GeographicaOeconomica” 1972, Vol.5 Kraków Oddział PAN w Krakowie, pp. 149-160.

[7] Chojnacki J., Wskaźniki strat powodziowych, „Gospodarka Wodna” 1994, No 10, pp. 227-231.

[8] Chojnacki J., Szacowanie strat powodziowych [in:] Model kompleksowej ochrony przed powodzia $w$ obszarze dorzecza górnej Wisty na przyktadzie województwa małopolskiego, ed. M. Maciejewski, IMGW, Kraków CD-ROM, 2000.

[9] Crichton, D., The risk triangle [in:] Natural disaster management, ed. J. Ingleton, London: Tudor Rose, 1999, pp. 102-103.

[10] Crichton, D., What can cities do to increase resilience? "Philosophical Transactions of the Royal Society" 2007, Vol. 365, pp. 2731-2739.

[11] Drożdżal E., Grabowski M., Kondziołka K., Olbracht J., Piórecki M., Radoń R., Ryłko A., Mapy ryzyka powodziowego - projekt pilotażowy $w$ zlewni Silnicy, „Gospodarka Wodna” 2009, No 1, pp. 19-29.

[12] Dutta, D., Herath S., Musiake K., A mathematical model for flood loss estimation, "Journal of Hydrology" 2003, Vol. 277, No 1, pp. 24-49.

[13] Dyrektywa 2007/60/WE Parlamentu Europejskiego i Rady z dnia 23 października 2007 r. w sprawie oceny ryzyka i zarządzania nim (Dyrektywa Powodziowa).

[14] Genovese E., A methodological approach to land use-based flood damage assessment in urban areas: Prague case study, European Communities, 2006.

[15] Granger K., Jones T., Leiba M., Scott G., Community Risk in Cairns: A Multihazard Risk Assessment. AGSO (Australian Geological Survey Organisation) Cities Project, Department of Industry, Science and Resources, Australia 1999. 
[16] Grocki R., Eliasiewicz R., Zagospodarowanie terenów zalewowych, seria: Ograniczanie skutków powodzi w skali lokalnej, Biuro koordynacji Projektu Banku Światowego, Wrocław 2001.

[17]ICPR, International commission for the protection of the Rhine, Non-structural flood plain management: Measures and their effectiveness, Koblenz, 2002, http://www.iksr.org/index.php (access: 20.09.2014 r.).

[18] Kelman, I., Spence R., An overview of flood actions on buildings, "Engineering Geology" 2004, 73, pp. 297-309.

[19]Kobojek E., Środowisko przyrodnicze dolin rzek nizinnych $i$ kierunki antropogenicznych przeksztatceń [in:] Prawne, administracyjne i środowiskowe uwarunkowania zagospodarowania dolin rzecznych, ed. B. Więzik, Wyższa Szkoła Administracji w Bielsku Białej, 2010, pp. 41-54.

[20] Konrad C. P., Effects of Urban Development on Flood, U.S. Department of the Interior, U.S. Geological Survey, USGS Fact Sheet FS-076-03, 2003, http://pubs.usgs.gov/fs/fs07603/, (access: 20.09.2014 r.).

[21] Konwencja w sprawie ochrony światowego dziedzictwa kulturalnego i naturalnego, przyjęta w Paryżu z dnia 16 listopada 1972 r. przez Konferencję Generalną Organizacji Narodów Zjednoczonych dla Wychowania, Nauki i Kultury na jej siedemnastej sesji (Dz. U. 1976 Nr 32 poz. 190).

[22]Liszewski S.: Tereny miejskie. Podział i klasyfikacja, Acta Universitatis Lodziensis. ZNUŁ. Nauki Matematyczno-Przyrodnicze, Folia Geographica, s. II, z. 15,1978

[23]Liszewski S., Przestrzeń miejska i jej organizacja, Geografia. Człowiek. Gospodarka, Kraków, 1997.

[24] Messner F., Meyer V.: Flood damage, vulnerability and risk perception challenges for flood damage research, UFZ Discussion Paper 13, 2005.

[25] Nachlik E.: Wykorzystanie BDOT w ocenie ryzyka powodziowego Problemy integracji przestrzennych informacji bazodanowych, VII Krakowskie Spotkania z INSPIRE, Georeferencyjne dane przestrzenne w INSPIRE - od zbiorów do usług danych przestrzennych, Kraków, 12-14 maja 2011.

[26] Nicholas, J., Holt G. D., Proverbs D.: Towards standardizing the assessment of flood damaged properties in the UK, Struct. Surv., vol. 19, no. 4, 2001, pp. 163172.

[27] Ocena zagrożenia powodziowego na obszarze województwa tódzkiego, Wydział Bezpieczeństwa i Zarządzania Kryzysowego, Łódzki Urząd Wojewódzki w Łodzi, Łódź 2012.

[28] Program Bezpieczeństwa Powodziowego $w$ regionie wodnym Środkowej Wisty, 2012, Warszawa;

[29] Regulski J., Planowanie przestrzenne, Państwowe Wydawnictwo Ekonomiczne, Warszawa, 1985.

[30] Ripl, W., Management of water cycle and energy flow for ecosystem control: The energy-transport-reaction (ETR) model, "Ecological Modelling" 1995, Vol. 78, pp. 61-76.

[31] Rotnicka J., Gospodarka wodna w świetle uwarunkowań Unii Europejskiej, [in:] Stan gospodarki wodnej w Polsce - problematyka prawna i kompetencyjna (na przykładzie Dolnej Wisły), Materiały z konferencji zorganizowanej przez 
Parlamentarny Zespół ds. Dróg Wodnych i Turystyki Wodnej 2 czerwca 2011 r. w siedzibie Senatu, Kancelaria Senatu.

[32] Rozporządzenie Ministra Środowiska, Ministra Transportu, Budownictwa i Gospodarki Morskiej, Ministra Administracji i Cyfryzacji oraz Ministra Spraw Wewnętrznych z dnia 21 grudnia 2012 r. w sprawie opracowywania map zagrożenia powodziowego oraz map ryzyka powodziowego, (Dz. U. 2013 poz. 104);

[33] Sayers P.B., Gouldby B.P., Simm J.D., Meadowcroft I., Hall J., Risk Performance and Uncertainty in Flood and Coastal Defence - AReview, R\&D Technical Report FD2302/TR1 (HR Wallingford Report SR587), Crown copyright, London, U.K., 2002.

[34] Słonecka A., Jaglak E, Goryszewska E., Kołakowska J., Ulanicka E., Zagospodarowanie przestrzenne dolin rzecznych a zagrożenie powodziowe województwa mazowieckiego, Mazowieckie Biuro Planowania Regionalnego, Warszawa, 2008.

[35] Sowiński M., Szkody powodziowe jako element wyznaczania ryzyka, „Infrastruktura i ekologia terenów wiejskich” 2008, No 7, Polska Akademia Nauk, Oddział w Krakowie, pp. 121-130.

[36] Szypuła M., Strefy zagrożenia powodziowego: metodyka określania rodzajów $i$ sposób wyznaczania $z$ wykorzystaniem numerycznego modelu terenu, „Gospodarka Wodna” 2001, No 8, pp. 328-330.

[37] Thieken A. H., Müller M., Kreibich H., Mer, B., Flood damage and influencing factors: New insights from the August 2002 flood in Germany, "Water Resources Research" 2005, 41, doi:10.1029/2005WR004177.

[38] Trzmiel B., Szczegółowa Mapa Geologiczna Polski, 1:50 000, arkusz 667Tomaszów Mazowiecki, Państwowy Instytut Geologiczny, Warszawa, 1986.

[39] UN DHA, Internationally Agreed Glossary of Basic Terms Related to Disaster Management. UN DHA (United Nations Department of Humanitarian Affairs), Geneva, 1992.

[40] Ustawa z dnia 21 listopada 1996 r. o muzeach (Dz. U. 1997 nr 5 poz. 24).

[41] Ustawa z dnia 23 lipca 2003 r. o ochronie zabytków i opiece nad zabytkami (Dz. U 2003 Nr 162 poz. 1568 z późn. zm.).

[42] Walczykiewicz T., Biedroń I., Zagospodarowanie dolin rzecznych $w$ świetle zarzadzania ryzykiem powodziowym [in:] Prawne, administracyjne $i$ środowiskowe uwarunkowania zagospodarowania dolin rzecznych, ed. B. Więzik, Wyższa Szkoła Administracji w Bielsku Białej, Bielsko Biała, 2013, pp. 145-154.

[43] Wind, H. G., Nierop T. M., de Blois C. J., de Kok J. L, Analysis of flood damages from the 1993 and 1995 Meuse flood, "Water Resources Research" 1999, Vol. 35, No 11, pp. 3459-3465.

[44] http://www.kzgw.gov.pl/Dyrektywa-Powodziowa.html (access: 27.11.2013). 
OCENA RYZYKA POWODZIOWEGO GMIN WOJEWÓDZTWA ŁÓDZKIEGO

$\mathrm{W}$ artykule za cel przyjęto ocenę ryzyka powodziowego na obszarach zagrożonych powodziami w 21 gminach województwa łódzkiego. Badaniu podlegał obszar szczególnego zagrożenia powodzią, za który przyjęto zasięg występowania wód o prawdopodobieństwie pojawienia się raz na 100 lat. Pojęcie ryzyka powodziowego oznacza natomiast „kombinację prawdopodobieństwa wystąpienia powodzi i związanych z nią potencjalnych negatywnych konsekwencji dla zdrowia ludzkiego, środowiska, dziedzictwa kulturowego oraz działalności gospodarczej" ${ }^{52}$. Do oceny ryzyka powodziowego posłużyła autorska metoda bonitacji punktowej, gdzie polem podstawowym był heksagon o powierzchni 0,5ha. Autorka dokonała zarówno syntetycznego poziomu ryzyka powodziowego, jak i jego zróżnicowania w obrębie terenu zagrożonego powodzią. Najwyższy syntetyczny poziom ryzyka powodziowego jest w Łowiczu oraz Tomaszowie Mazowieckim (mieście). Na obszarze Łowicza, dno doliny Bzury jest bardzo szerokie, w szczególności w zachodniej i wschodniej części, tam też lokalizowana jest zabudowa. Tomaszów Mazowiecki, to miasto w którym do Pilicy uchodzą mniejsze rzeki, w związku z czym dno doliny osiąga tu znaczne rozmiary, co sprzyja lokalizowaniu zabudowy. Mniejsze rzeki, w szczególności Czarna, Piasecznica oraz położenie poniżej zbiornika Sulejowskiego, stwarza wśród użytkowników tych obszarów poczucie bezpieczeństwa. Wszystko to prowadzi do intensyfikacji zagospodarowania na tych terenach oraz wzrostu związanych z tym potencjalnych, negatywnych konsekwencji w przypadku nadejścia powodzi. Analiza poziomu ryzyka powodziowego jest niezwykle istotna i umożliwia prowadzenie odpowiedniej polityki ochrony przeciwpowodziowej.

Słowa kluczowe: tereny zagrożone powodziami, zagospodarowanie przestrzenne, ryzyko powodziowe, Dyrektywa Powodziowa.

DOI:10.7862/rz.2015.hss.1

Przesłano do redakcji: październik 2014

Przyjęto do druku: czerwiec 2015

\footnotetext{
${ }^{52}$ Dyrektywa 2007/60/WE Parlamentu Europejskiego i Rady z dnia 23 października 2007 r. w sprawie oceny ryzyka i zarządzania nim (Dyrektywa Powodziowa), art. 2 pkt. 2.
} 